\title{
Effect of LDL-apheresis on plasma lipids, chitotriosidase and anti-oxLDL antibodies in heterozygous familial hypercholesterolemia
}

\author{
Maria Musumeci ${ }^{1}$, Francesco Pappalardo ${ }^{2,3}$, GianCarlo Tonolo ${ }^{4}$, Fernando Torrisi ${ }^{5}$, Francesca Gullo ${ }^{3}$, \\ Salvatore Musumeci ${ }^{6}$
}

\begin{abstract}
${ }^{1}$ Department of Hematology, Oncology and Molecular Medicine, Italian National Institute of Health, Rome, Italy; ${ }^{2}$ Institute for Computing Applications "M. Picone", National Research Council (CNR), Rome, Italy; ${ }^{3}$ University of Catania, Catania, Italy; ${ }^{4}$ Diabetology Unit, Azienda Sanitaria Locale 2 Olbia, Italy affiliated to Department of Clinical Sciences, Medical Genetics Unit, Lund University, Malmö, Sweden; ${ }^{5}$ Institute of Medical and Environmental Research (IRMA), Acireale (Catania), Italy; ${ }^{6}$ Department of Neurosciences and Mother to Child Sciences, University of Sassari, and Institute of Biomolecular Chemistry, National Research Council (CNR), Li Punti, Sassari, Italy.

Email: smusumeci@tiscalinet.it
\end{abstract}

Received 16 June 2009; revised 10 July 2009; accepted 17 July 2009.

\section{ABSTRACT}

Forty four consecutive subjects aged 29-58 years (21 males and 23 females) with a clinical diagnosis of heterozygous familial hypercholesterolemia periodically treated every 30 days with LDL-apheresis for statin resistance, were enrolled in this study. A lipid profile was obtained immediately before starting LDL-apheresis, a second profile was obtained within four hours after LDL-apheresis. Chit activity and anti-oxLDL levels were determined with appropriate methods in all patients before and after LDLapheresis. Total cholesterol, LDL-cholesterol, HDLcholesterol and triglycerides decreased significantly after LDL-apheresis, while the variations of Chit activity and anti-oxLDL were not significant after LDL-apheresis. The correlation between Chit and total cholesterol was negative $(r=-0.44$ and -0.50 respectively) before and after LDL-apheresis as between Chit and LDL-cholesterol $(r=-0.45$ and -0.55 respectively). Anti-oxLDL concentration before and after LDL-apheresis positively correlated with Chit activity $(r=0.52$ and $r=0.63$ respectively), negatively with total cholesterol $(r=-0.33$ and $r=-0.35$ respectively) and with LDL $(r=-0.32$ and $r=-0.21$ respectively). We think that removing LDL with LDL-apheresis the anti-oxLDL/oxLDL ratio could increase and the excess of anti-oxLDL could induce macrophage activation through the surface Fc receptors. Alternatively with high levels of LDLcholesterol, the deposition of foam cells represent the characteristic evolution of atherosclerosis process. Macrophage activation in the heterozygous familial hypercholesterolemia could represent an attempt for re-modeling the vessel wall, reducing the growth of lipid plaques.

Keywords: LDL-Apheresis; Heterozygous Familial HyperCholesterolemia; Lipids; Chitotriosidase; Anti-oxLDL Antibodies; Sardinia

\section{INTRODUCTION}

Familial hypercholesterolemia $(\mathrm{FH})$ is a genetic alteration of lipoprotein metabolism caused by defects in the low density lipoprotein receptor (LDLR) [1]. High LDL levels, secondary to the LDLR homozygous defect, are associated to significant increase of oxidized LDL (oxLDL), which removed from circulation lead to massive lipid accumulation, foam cell formation in endothelial wall, often tendom xanthomas (TX) and corneal arcus [2]. Also the heterozygous FH (heFH), shows precocious coronary heart disease before 65 years old, if they are not treated [3]. Then FH represent a paradigmatic example of atherosclerosis produced by oxLDL accumulation and a model to study the role of macrophage activation in atherosclerosis process [1]. Generated oxLDL induces an immune response with production of anti-oxLDL antibodies and macrophage cells could remove from circulation immune complexes anti-oxLDL/oxLDL through the $\mathrm{Fc}$ receptor for antibodies [4]. Shoji et al 2000 [5] found a inverse correlation among anti-oxLDL and oxLDL in healthy individuals supporting the hypothesis that this mechanism is also operating in condition where oxLDL are 
stably low. This mechanism could be not sufficient to protect from foam cells generation in presence of a defect in LDLR gene, when the levels of oxLDL are very high [6].

Chitotriosidase (Chit) is one of the most quantitatively represented marker of macrophage activation, such as occurs in Gaucher disease, sarcoidosis, nonalcoholic liver disease and atherosclerosis [7,8,9]. Plasma Chit activity has been associated with both the extension and prognosis of atherosclerotic vascular lesions in humans $[10,11,12]$ and its phagocyte-specific expression supports a relevant role in innate immunity [13].

Considering the importance of anti-oxLDL in the pathogenesis of atherosclerosis lesions [14] and the involvement of Chit activity in the evolution of atherosclerotic vascular lesions [10,11], we hypothesize a relation among these two factors. The objective of this study is to establish the relationship between lipid parameters, Chit activity and anti-oxLDL levels in a group of subjects with clinically and genetically defined heFH (total cholesterol consistently more than $400 \mathrm{mg} / \mathrm{dl}$ ) before and after LDL-apheresis treatment. LDL-apheresis represents an effective therapy in heFH patients, who had no response to highest doses of statin drugs, and could restore the physiological mechanism of antioxLDL/oxLDL immunocomplexes clearance altered by LDLR genetic defect [15].

\section{MATERIAL AND METHODS}

\subsection{Study Subjects}

Consecutive 44 subjects from Sardinia (Italy) aged 2958 years $(21$ males and 23 females) with a clinical diagnosis of heFH were treated periodically with LDLapheresis. The diagnosis of heFH was determined genetically in all patients [2]. They started LDL-apheresis treatment because their previous lipid lowering therapy (statin and benzafibrate) did not reduce the total and LDL cholesterol.

A combination of discontinuous blood centrifugation (MCS 3p Haemonetics Corp., Braintree, MA, USA) and 2 steps membrane differential filtration were performed at interval of 30 days. Clinical data, history of prior cardiovascular disease (CVD) at early onset, demographic and anthropometric measurements, and an accurate physical examination in search of tendon xanthomas (TX) were obtained from each subject.

Informed consent was obtained from all subjects and the ethical committee from each institution approved this study.

\subsection{Lipid Concentrations}

To obtain a baseline lipid profile, overnight fasting blood was drawn immediately before starting LDL-apheresis. A second profile was obtained within four hours after
LDL-apheresis. Total cholesterol and triglyceride levels were measured with standardized enzymatic methods. HDL cholesterol was measured by precipitation methods and LDL cholesterol was estimated with the Friedewald's formula, since no patient had triglycerides over $300 \mathrm{mg} / \mathrm{dl}$. Lipoprotein (a) was determined in immunonephelometry with specific antibodies (New Scientific Company S.r.L., Cormano (MI), Italy).

\subsection{Chitotriosidase Enzyme Assay}

Chitotriosidase enzyme assay was based on the method described by Hollak et al. 1994 [7], with minor modifications. Briefly, chitotriosidase activity was determined by incubating $5 \mu \mathrm{L}$ of plasma with $100 \mu \mathrm{L}$ of $22 \mathrm{mmol} / \mathrm{L}$ 4-methylumbelliferyl- $\beta-\mathrm{d}-\mathrm{N}, \mathrm{N}^{\prime}, \mathrm{N}^{\prime \prime}$ triacetyl-chitotrioside fluorogenic substrate (Sigma-Aldrich S.r.L. Milano, Italy, catalogue M 5639) in Mcllvain buffer $(100 \mathrm{mmol} / \mathrm{L}$ citric acid and $200 \mathrm{mmol} / \mathrm{L}$ sodium phosphate, $\mathrm{pH}$ 5.2) for 15 minutes at $37^{\circ} \mathrm{C}$. The reaction was stopped by using $2 \mathrm{ml}$ of $0.5 \mathrm{~mol} / \mathrm{L} \mathrm{Na}_{2} \mathrm{CO}_{3}-\mathrm{NaHCO}_{3}$ buffer, $\mathrm{pH}$ 10.7. The substrate hydrolysis by Chit produces the fluorescent molecule 4-methylumbelliferone, which was quantified with a Hitachi 2500 fluorometer, excitation at $366 \mathrm{~nm}$ and emission at $446 \mathrm{~nm}$, and compared with a standard 4-methylumbelliferone calibration curve. Chit activity was expressed as nanomoles of substrate hydrolyzed per hour per milliliter of reaction mixture. Plasma Chit activity was measured by duplication and three QC samples from healthy adults were added in every set of determinations. The coefficient of variation was less than $5 \%$ in all cases.

\subsection{Oxidized Low-Density Lipoprotein Antibodies}

An enzyme-linked immunosorbent assay (ELISA) for the detection and quantification of IgG antibodies to oxidized low-density lipoprotein (oxLDL) in human plasma was used (ImmuLisa ${ }^{\mathrm{TM}}$, IMMCO Diagnostics, Buffalo, NY, USA). The intensity of the color changes, proportionally to the antibodies concentration, was read as absorbance at $405 \mathrm{~nm}$. Three QC samples from healthy adults were also added in each plate containing a calibration curve. The absorbance values on native LDL were subtracted from the absorbance obtained on oxLDL for control, calibrators and specimens. The concentration of anti-oxLDL was determined from the calibration curve and the results are expressed in Enzyme Units per milliliter (EU/ml).

\subsection{Apolipoprotein E Genotyping}

DNA from patients isolated by peripheral blood cells was used in a polymerase chain reaction (PCR) and Apolipoprotein E genotypes were determined by HhaI digestion as the methods described by Hixon and Vernier [16], modified by Tsukamoto et al [17]. 


\subsection{LDLR Genetic Analyses}

For LDLR gene analysis the entire gene was sequenced. Mutations in the LDLR gene causing FH were classified when possible, as receptor-defective or receptor-negative on the basis of the residual LDLR activity. Mutation leading to a frame-shift and/or a truncated receptor were considered as receptor-negative $[2,6]$.

\subsection{Chitotriosidase Polymorphism}

DNA from patients were used as template in subsequent PCR reactions. The duplication mutation analysis was performed using specific primers [Chs9 (AGCTATCT GAAGCAGAAG) and Chas8 (GGAGAAGCCGGCAAAGTC)] and two fragments of 75 and 99 base pairs were amplified from the wild and mutant CHIT gene, respectively. Electrophoresis in Metaphore gel (4\%), allowed the detection of both fragments.

\section{STATISTICAL METHODS}

The data are expressed as mean values with standard deviation (SD) for variables with normal distribution and as medians and range for variables with a skewed distribution. Statistical differences were computed by using the Student's $t$ test or the Mann-Whitney U-test, respectively. Correlation and statistical analyses were performed with SSPS software (version 13.0), with significance set at $\mathrm{P}<0.05$.

\section{RESULTS}

In Table 1, we show the clinical and biochemical characteristics of the 44 heFH subjects, including also the LDLR and CHIT genotype polymorphisms. No signi- ficant difference, among men and women, regarding age, body mass index, blood pressure was found and neither presence of hypertension nor diabetes. Differences were found in smoking habit, premature CVD, and age of first CVD event, being more smoker among the men group, who had more premature CVD, with minor age at the first event. Mean values of total cholesterol, LDL- cholesterol, triglycerides in the last few months were elevated in all subjects with no significant difference between men and women (see Table 1). Only men had significantly lower HDL cholesterol levels compared to women. No Chit deficient patients was found at the genotype analysis, 27 (61.4\%) were wild/wild and 17 (38.6\%) wild/mut. Chit activity was found elevated before LDL-apheresis, without difference between males $(11.94+8.68 \mathrm{nmol} / \mathrm{ml} / \mathrm{h})$ and females $(12.26 \pm 7.70 \mathrm{nmol} / \mathrm{ml} / \mathrm{h})$, considering that $7.3 \pm 1.9 \mathrm{nmol} / \mathrm{ml} / \mathrm{h}$ activity was found in healthy control of the same age in our laboratory. Also the anti-oxLDL were found elevated before LDL-apheresis in males $(38.20 \pm 17.64 \mathrm{UI} / \mathrm{ml})$ and in females $(55.80 \pm 38.97)$, considering that $<20 \mathrm{UI} / \mathrm{ml}$ was found in healthy control
Table 1. Clinical and laboratory characteristics of 44 heterozygous $\mathrm{FH}$ patients (21 men and 23 women).

\begin{tabular}{|c|c|c|c|}
\hline & $\begin{array}{c}\text { Men } \\
\mathrm{N}=21\end{array}$ & $\begin{array}{l}\text { Women } \\
\mathrm{N}=23\end{array}$ & $\mathrm{p}$ \\
\hline Age, years & $35.2(29-54)$ & $36.9(32-58)$ & N.S. \\
\hline Body mass index, $\mathrm{kg} / \mathrm{m} 2$ & $28.0 \pm 3.68$ & $28.5 \pm 4.84$ & N.S. \\
\hline $\begin{array}{l}\text { Smoking status: } \\
\text { Never, n (\%) } \\
\text { Current, n (\%) } \\
\text { Former, n (\%) }\end{array}$ & $\begin{array}{c}7(33.3) \\
3(14.3) \\
11(52.4)\end{array}$ & $\begin{array}{c}15(65.2) \\
5(21.7) \\
3(13.0)\end{array}$ & 0.0001 \\
\hline Smoking, packs x years & $26.1 \pm 10.0$ & $26.5 \pm 7.42$ & N.S. \\
\hline Systolic blood pressure, $\mathrm{mmHg}$ & $130.3 \pm 17.1$ & $129.4 \pm 19.1$ & N.S. \\
\hline Diastolic blood pressure, $\mathrm{mmHg}$ & $77.4 \pm 10.3$ & $76.8 \pm 11.3$ & N.S. \\
\hline Hypertension, $\mathrm{n}(\%)$ & $4(19.0)$ & $5(21.7)$ & N.S. \\
\hline Diabetes, n (\%) & $1(4.8)$ & $1(4.3)$ & N.S. \\
\hline Premature CVD, n (\%) & $8(38.1)$ & $6(26.1)$ & 0.016 \\
\hline Age of first CVD event, years & $45.4+6.16$ & $49.5 \pm 7.53$ & 0.0578 \\
\hline $\begin{array}{c}\text { Family history premature CVD, } \\
\text { n. (\%) }\end{array}$ & $10(47.6)$ & $11(47.8)$ & N.S. \\
\hline Tendon xanthomas, n. (\%) & $8(38.1)$ & $11(47.8)$ & N.S. \\
\hline Total cholesterol, $\mathrm{mmol} / \mathrm{L}$ & $8.99 \pm 4.03$ & $8.29 \pm 1.53$ & N.S. \\
\hline Triglycerides, $\mathrm{mmol} / \mathrm{L}$ & $1.46 \pm 1.24$ & $1.04 \pm 0.53$ & N.S. \\
\hline LDL cholesterol, $\mathrm{mmol} / \mathrm{L}$ & $7.25 \pm 1.20$ & $6.82 \pm 1.33$ & N.S. \\
\hline HDL cholesterol, mmol/L & $1.33 \pm 0.28$ & $1.48 \pm 0.35$ & 0.0228 \\
\hline Chitotriosidase (nmol/ml/hr) & $11.94 \pm 8.68$ & $12.26 \pm 7.70$ & N.S. \\
\hline Anti-oxLDL (UI/ml) & $38.20 \pm 17.64$ & $55.80 \pm 38.97$ & 0.0646 \\
\hline $\begin{array}{c}\text { ApoE genotype } \\
\text { E3/E3, n (\%) } \\
\text { E3/E4, n (\%) } \\
\text { E3/E2, n (\%) } \\
\text { E4/E4, n (\%) } \\
\text { E2/E2, n (\%) }\end{array}$ & $\begin{array}{c}16(76.2) \\
5(23.8-0) \\
0(0) \\
0(0) \\
0(0)\end{array}$ & $\begin{array}{c}16(69.6) \\
5(21.7) \\
2(8.7) \\
0(0) \\
0(0)\end{array}$ & N.S. \\
\hline $\begin{array}{l}\text { LDLR gene mutation } \\
\text { Defective, } \mathrm{n}(\%) \\
\text { Negative, } \mathrm{n}(\%) \\
\text { Undefined, } \mathrm{n}(\%)\end{array}$ & $\begin{array}{l}9(45.0) \\
7(35.0) \\
4(20.0)\end{array}$ & $\begin{array}{l}8(33.7) \\
9(39.1) \\
6(26.1)\end{array}$ & N.S. \\
\hline $\begin{array}{l}\text { Chit gene mutation } \\
\text { Mut/Mut, n (\%) } \\
\text { Wild/Mut, n (\%) } \\
\text { Wild/Wild,n (\%) }\end{array}$ & $\begin{array}{c}0(0) \\
13(61.9) \\
8(38.1)\end{array}$ & $\begin{array}{c}0(0) \\
14(60.8) \\
9(39.2)\end{array}$ & N.S. \\
\hline
\end{tabular}

of the same age in our laboratory. The difference between males and females was not significant $(\mathrm{P}=$ 0.0646). In Table 2 are reported the levels of total cholesterol, LDL-cholesterol, HDL-cholesterol, triglycerides, Chit and anti-oxLDL before and after LDLapheresis, considering separately males and females. All lipid parameters significantly decreased after LDLapheresis $(\mathrm{P}<0.0001)$. The reduction of Chit activity after LDL-apheresis was not significant as well as the 
Table 2. Lipid parameters before and after plasmapheresis in 44 heterozygous FH patients (21 men and 23 women).

\begin{tabular}{|c|c|c|c|c|c|}
\hline & & & Before Plasmapheresis & After Plasmapheresis & Student $\mathrm{T}$ test \\
\hline $\begin{array}{l}\text { Total cholesterol, } \\
\text { " }\end{array}$ & $"$ & $\begin{array}{c}\text { (men) } \\
\text { (women) }\end{array}$ & $\begin{array}{l}8.99 \pm 4.03 \\
8.29 \pm 1.53\end{array}$ & $\begin{array}{l}3.23 \pm 0.85 \\
2.98 \pm 0.70\end{array}$ & $\begin{array}{l}0.0001 \\
0.0001\end{array}$ \\
\hline $\begin{array}{l}\text { Triglycerides, } \mathrm{mmol} / \mathrm{L} \\
\text { " }\end{array}$ & " & $\begin{array}{l}\text { (men) } \\
\text { (women) }\end{array}$ & $\begin{array}{l}1.46 \pm 1.24 \\
1.04 \pm 0.53\end{array}$ & $\begin{array}{l}0.62 \pm 0.26 \\
0.44 \pm 0.21\end{array}$ & $\begin{array}{l}0.0001 \\
0.0001\end{array}$ \\
\hline$\underset{"}{\mathrm{LDL}} \underset{\prime}{ }$ & $"$ & $\begin{array}{c}\text { (men) } \\
\text { (women) }\end{array}$ & $\begin{array}{l}7.25 \pm 1.20 \\
6.82 \pm 1.33\end{array}$ & $\begin{array}{l}2.10 \pm 0.74 \\
1.97 \pm 0.63\end{array}$ & $\begin{array}{l}0.0001 \\
0.0001\end{array}$ \\
\hline $\begin{array}{l}\mathrm{HDL} \text { cholesterol, }{ }_{\prime \prime}^{\mathrm{mmol} / \mathrm{L}} \\
\text { " }\end{array}$ & $"$ & $\begin{array}{c}\text { (men) } \\
\text { (women) }\end{array}$ & $\begin{array}{l}1.33 \pm 0.28 \\
1.48 \pm 0.35\end{array}$ & $\begin{array}{l}0.93 \pm 0.21 \\
1.03 \pm 0.22\end{array}$ & $\begin{array}{l}0.0001 \\
0.0001\end{array}$ \\
\hline $\begin{array}{l}\text { Chitotriosidase }\left(\mathrm{nmol}^{\prime} / \mathrm{ml} / \mathrm{hr}\right) \\
\text { " }\end{array}$ & r) & $\begin{array}{c}\text { (men) } \\
\text { (women) }\end{array}$ & $\begin{array}{l}11.94 \pm 8.68 \\
12.26 \pm 7.70\end{array}$ & $\begin{array}{l}9.04 \pm 4.36 \\
9.16 \pm 4.92\end{array}$ & $\begin{array}{l}\text { N.S. } \\
\text { N.S. }\end{array}$ \\
\hline$\underset{\iota "}{\text { Anti ox-LDL }} \underset{\prime \prime}{(\mathrm{UI} / \mathrm{ml})}$ & " & $\begin{array}{l}\text { (men) } \\
\text { (women) }\end{array}$ & $\begin{array}{l}30.20 \pm 17.64 \\
55.80 \pm 38.97\end{array}$ & $\begin{array}{l}26.45 \pm 15.48 \\
48.00 \pm 30.01\end{array}$ & $\begin{array}{l}\text { N.S. } \\
\text { N.S. }\end{array}$ \\
\hline
\end{tabular}

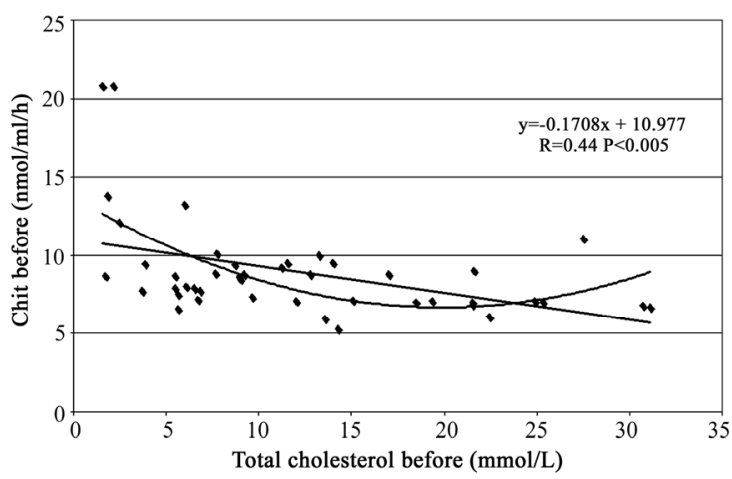

(a)

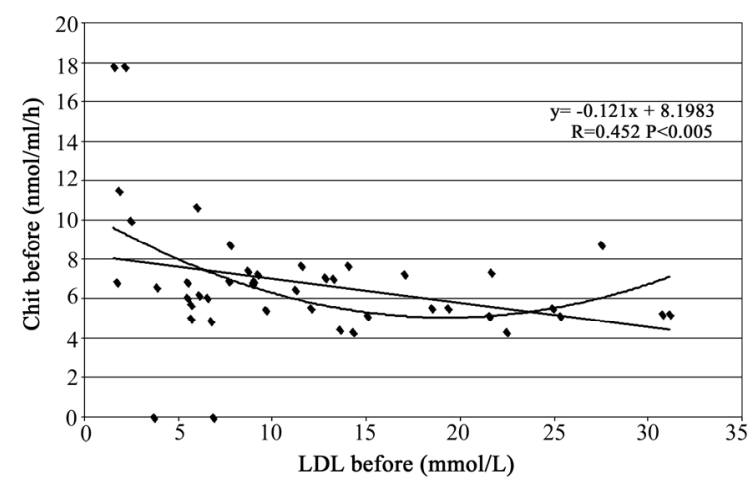

(c)

Figure 1.

reduction of anti-oxLDL concentration. Before and after LDL-apheresis the correlation between Chit and total cholesterol was negative ( $\mathrm{r}=-0.44$ and -0.50 respectively) and the same between Chit and LDL-cholesterol $(\mathrm{r}=$ -0.45 and -0.55 respectively) Figures $1 \mathrm{a}, \mathrm{b}, \mathrm{c}, \mathbf{d})$. The correlation between HDL-cholesterol and Chit before and after LDL-apheresis was not significant. The antioxLDL concentration positively correlated with Chit activity $(\mathrm{r}=0.52)$ and negatively with LDL-cholesterol $(\mathrm{r}=-0.32)$ and total cholesterol $(\mathrm{r}=-0.33)$ before LDL-apheresis (Figures 2a, c, e). After LDL-apheresis the correlation with Chit was maintained high $(r=0.63)$ and the correlation with LDL-cholesterol and total

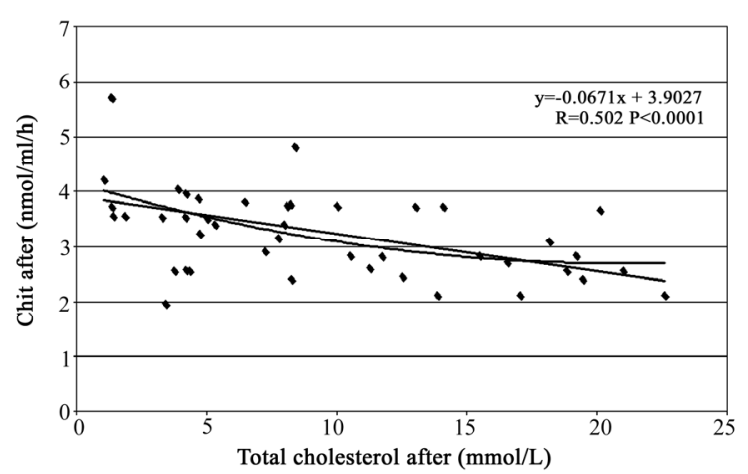

(b)

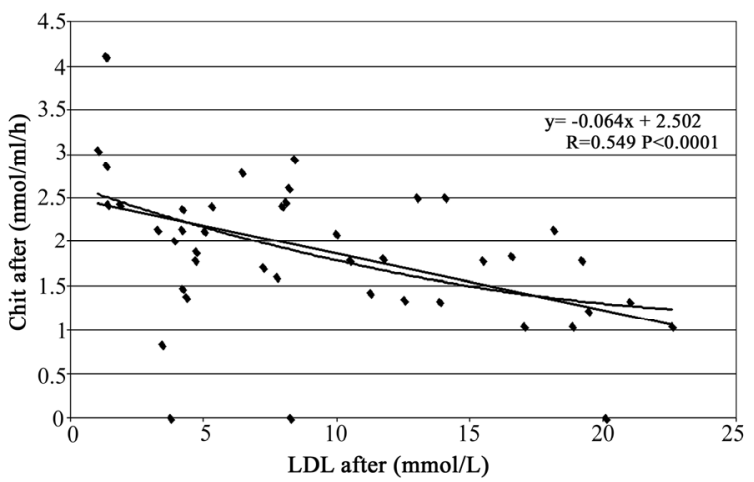

(d)

cholesterol remained significant $(r=-0.21$ and $r=-0.35$ respectively) (see Figures $\mathbf{2 b}, \mathbf{d}, \mathbf{f}$ ).

However negative correlations were not maintained for high levels of total cholesterol and LDL-cholesterol, before LDL-apheresis. This was supported by the order2 polynomial trend behavior showed in Figures 1a and c, Figures 2c and e. On the contrary, these trends were maintained, when the level of total cholesterol and LDL-cholesterol decreased after LDL-apheresis.

\section{DISCUSSION}

Plasma filtration represent an effective therapy in heFH 
patients, who had no response to highest doses of statin and could restore through a macrophage activation the physiological mechanism of remotion of anti-oxLDL/ oxLDL immunocomplexes altered by LDLR genetic defect [15].

In fact in this study we demonstrated a negative correlation among Chit activity, total and LDL-cholesterol before and after LDL-apheresis, which seems to be dependent by active macrophage removal of antioxLDL/oxLDL immunocomplexes.

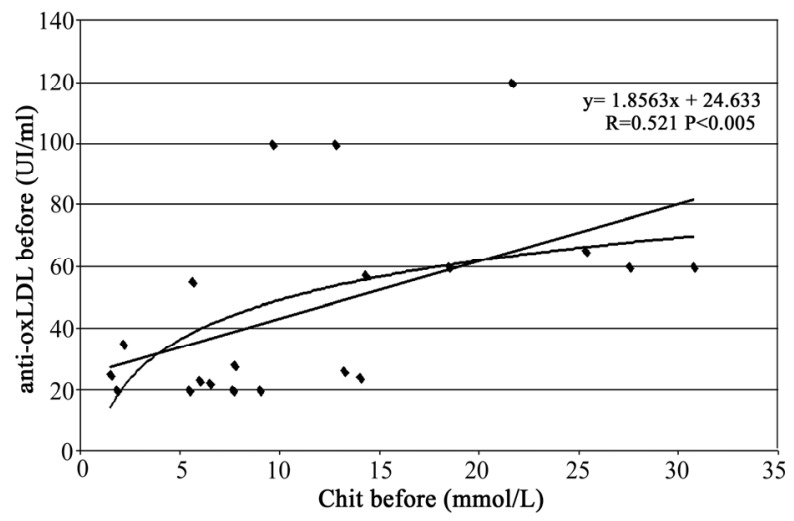

(a)

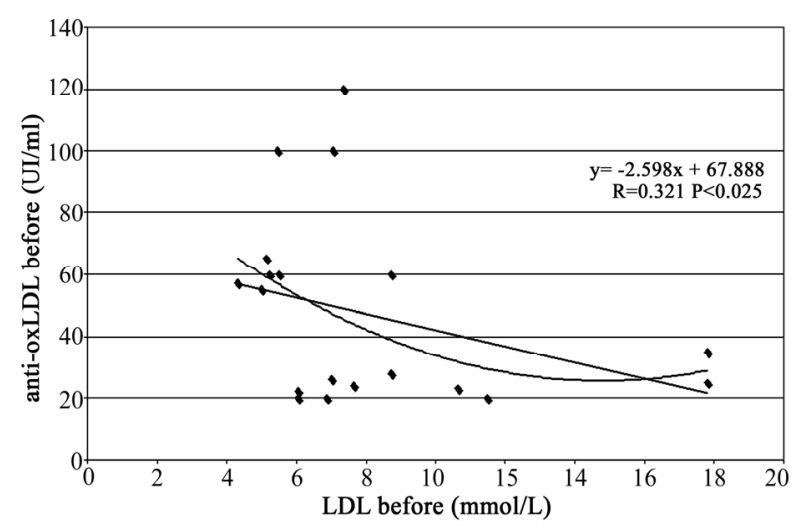

(c)

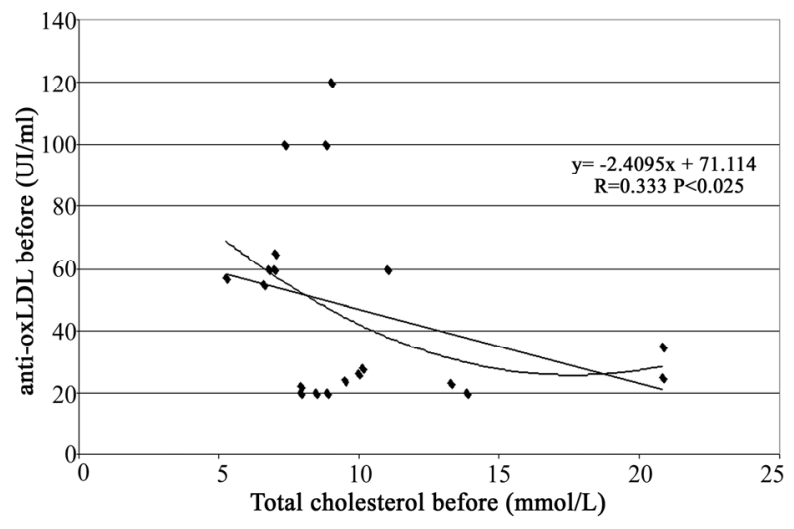

(e)
By removing LDL with LDL-apheresis, the antioxLDL/oxLDL ratio could increase and the excess of anti-oxLDL could induce macrophage activation through the surface $\mathrm{Fc}$ receptors. Alternatively with high levels of LDL-cholesterol, the deposition of foam cells represent the natural evolution of atherosclerosis process (as highlighted by the trend inversion above mentioned).

Hulthe et al 1998 [18] found, in a post hoc analysis, lower antibody titers in patients with a history of myocardial infarction, suggesting that antibodies against

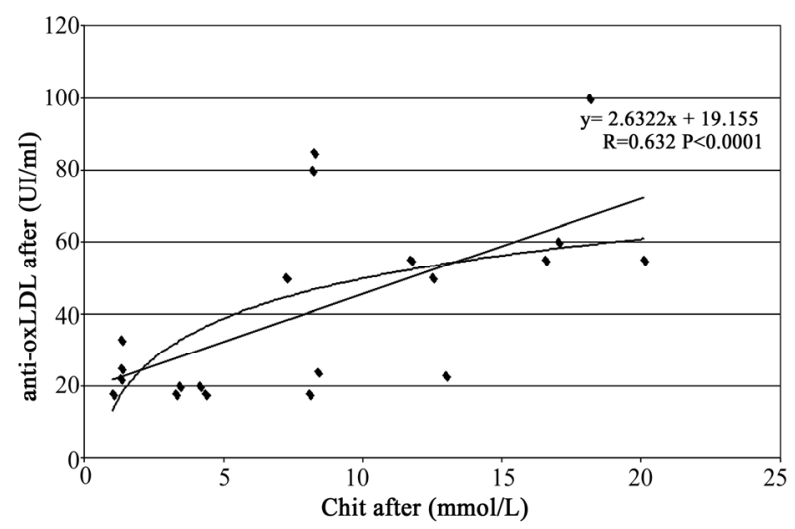

(b)

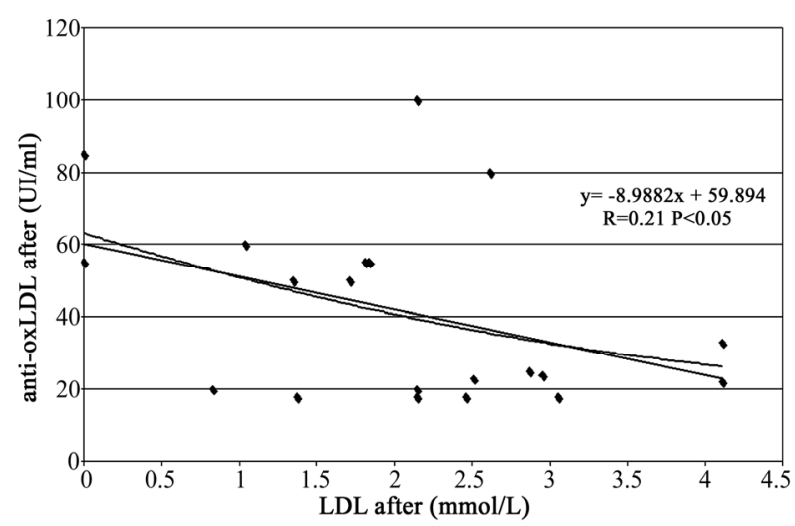

(d)

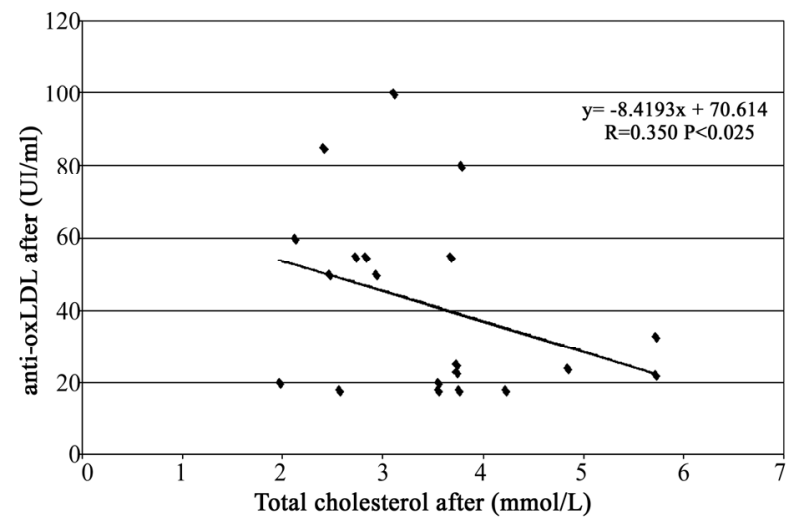

(f)

Figure 2. 
oxLDL could have a protective effect. This observation is in agreement with Tinahones et al 2002 [19], who reported in literature a negative correlation among anti-oxLDL and total cholesterol in a population of 400 subjects from Malaga (Spain), suggesting again the active role of macrophage cells in the remotion of oxLDL. The same authors [20] in a larger population (1354 subjects) found a very significant increase $(\mathrm{P}<$ $0.0001)$ of anti-oxLDL: younger persons (16-35 years) had higher levels of anti-oxLDL (MDA-LDL) antibodies than persons older than 35 years $(\mathrm{P}=0.05)$ and immune complexes were significantly higher $(\mathrm{P}=0.05)$ in persons aged 5-15 years than in persons older than 40 years. On the contrary Artieda et al 2003 [10] reported an increased plasma Chit activity, independent from the distinct allelic or genotype distribution, in Spanish patients with atherothrombotic stroke and correlated plasma Chit activity to the severity of the atherosclerotic lesion [11]. Moreover, in Spanish hypercholesterolemic patients Canudas et al [21] found that no correlation exist between plasma Chit activity and the variation of plasma lipid levels before and after treatment with atorvastatin or bezafibrate. In our study plasma Chit activity, total and LDL-cholesterol levels correlated negatively before and after LDL-apheresis. These contrasting results could be due to different mechanism depending from the high level of oxLDL in plasma, which could inhibit the re-modeling of vessel wall in defect of anti-oxLDL.

In fact the activation of macrophages within the atherosclerotic lesion could represent an attempt for re-modeling the vessel wall, which may control the growth of lipid plaques. In condition where the total cholesterol and LDL-cholesterol levels are maintained elevated, the negative trend which seems to demonstrate an active mechanism of immunocomplexes removal disappears, supporting the foam cells formation and subsequent deposition. Some years ago we demonstrated "in vitro" that the activation of macrophages was induced by formation of immunocomplexes anti-oxLDL/ oxLDL through the Fc fragment receptor on the macrophage cell surface [22]. Recently this hypothesis was resumed by Fostergard et al 2007 [23] who demonstrated the importance of antibodies response, comparing two populations with different cardiovascular disease prevalence from New Guinea and from Sweeden. The discriminant factor among this two groups was a significant level of anti-phosphorylcholine antibodies of IgM subclass, which are active in the remotion of oxLDL. Also in atherosclerosis mice model, the induced increase of anti-oxLDL appears to be protective, in fact several investigators have demonstrated with oxLDL immunization [24,25] or with S. Pneumoniae immunization [26], that in such model the atherosclerosis development attenuates. This was also confirmed by an "in vivo" study in Watanabe heritable hyperlipidemic rabbits, lacking the LDL receptor and mimicking the human familial hypercho-lesterolemia. In this mice model the continuous auto-immunization with malondialdehyde-modified LDL, miming oxLDL, results in a very high concentration of antibodies against oxLDL, leading to significantly reduced progression of atherosclerosis [27]. This experiment opens the way to a model for the oxLDL vaccination, with the aim to activate the macrophage system to clean the atheromatosis lesions. Moreover it is evident that the mechanism of active cleaning of atheromatosis lesions is working when the level of total cholesterol and LDL-cholesterol is kept sufficiently low [5].

This evidence was also supported by our computational model that was able to reproduce experimental data and is actually used for making predictions and evaluate biological hypothesis [28].

In fact, LDL-apheresis is, up to date, the more active system for lowering LDL level in $\mathrm{FH}$, and we found a negative correlation between anti-oxLDL, total cholesterol and LDL-cholesterol before and after LDLapheresis, even plasma Chit activity and total and LDL-cholesterol correlated negatively before and after treatment. This stable response is explained by active remotion of immunocomplexes in these patients in the interval between LDL-apheresis. The increase of Chit activity was not found after statin treatment, probably because the modification of total cholesterol and LDL was not rapid enough to induce an activation of macrophage cells [21]. On the contrary Orem et al 2002 [29] reported after lipid lowering therapy with atorvastatin (10 mg/day) a significant decrement of anti-oxLDL and an increase of anti oxidant capacity of plasma LDL, which suggested again an active removal of immune complexes. They suggest also that the measurement of antibodies against oxLDL during lipid-lowering therapy may be used as an important marker for monitoring in-vivo LDL oxidation and atherosclerosis processes.

In individuals where the LDL were reduced by LDLapheresis or by statine treatment, an active mechanism may be operative clearing the surface of vessel as was reported in our beta-thalassemia patients [30] and in diabetes patients in statine treatment [22] protecting from oxLDL vascular alteration.

\section{ACKNOWLEDGEMENTS}

Authors are grateful to Mister Rapicavoli Giuseppe, laboratory technician, for his precious assistance in the preparation of samples and in the determination of chitotriosidase activity.

\section{AUTHORS CONTRIBUTION}

Authors have equally contributed to the manuscript.

\section{REFERENCES}

[1] Goldstein, J. L., Hobbs, H. H., and Brown, M. S., (2001) Familial hypercholesterolemia, The Metabolic and Molecular Basis of Inherited Disease, Scriver CR, Beaudet, A. L., Sly, W. S., Valle D, eds., McGraw-Hill, New York, 2863-2913.

[2] Ross, R., (1999) Atherosclerosis: An inflammatory 
disease, N. Engl. J. Med., 340, 115-126.

[3] Civeira, F., (2004) Guidelines for the diagnosis and management of heterozygous familial hypercholesterolemia, Atherosclerosis, 173, 55-68.

[4] Kern, F., (1990) Cholesterol metabolism, LDL, and the LDL receptor, Edited by Myant NB, Academic press, NewYork, 465.

[5] Shoji, T., Nishizawa, Y., Fukumoto, M., Shimamura, K., Kimura J., Kanda, H., et al., (2000) Inverse relationship between circulating oxidized low density lipoprotein (oxLDL) and anti-oxLDL antibody levels in healthy subjects. Atherosclerosis; 148, 171-7.

[6] Bertolini, S., Cantafora, A., Averna, M., Cortese, C., Motti, C., Martini, S., et al., (2000) Clinical expression of familial hypercholesterolemia in clusters of mutations of the LDL receptor gene that cause a receptor-defective or receptor-negative phenotype, Arterioscler Thromb Vasc Biol, 20, 41-52.

[7] Hollak, C. E., van Weely, S., van Oers, M. H., and Aerts, J. M., (1994) Marked elevation of plasma chitotriosidase activity, A novel hallmark of Gaucher disease, J. Clin. Invest., 93, 1288-1292.

[8] Boot, R. G., van Achterberg, T. A., van Aken, B. E., Renkema, G. H., Jacobs, M. J., Aerts, J. M., et al., (1999) Strong induction of members of the chitinase family of proteins in atherosclerosis: Chitotriosidase and human cartilage gp-39 expressed in lesion macrophages, Arterioscler Thromb Vasc Biol, 19, 687-694.

[9] Malaguarnera, L., Di Rosa, M., Zambito, A. M., dell'Ombra, N., Nicoletti, F., and Malaguarnera, M., (2006) Chitotriosidase gene expression in Kupffer cells from patients with non- alcoholic fatty liver disease, Gut, 55, 1313-1320.

[10] Artieda, M., Cenarro, A., Gañán, A., Jericó, I., Gonzalvo, C., Casado, J. M., et al., (2003) Serum chitotriosidase activity is increased in subjects with atherosclerosis disease, Arterioscler Thromb Vasc Biol., 23, 1645-1652.

[11] Artieda, M., Cenarro, A., Gañán, A., Lukic, A., Moreno, E., Puzo, J., et al., (2007) Serum chitotriosidase activity, a marker of activated macrophages, predicts new cardiovascular events independently of C-Reactive Protein, Cardiology, 108, 297-306.

[12] Hansson, G. K., (2005) Inflammation, atherosclerosis, and coronary artery disease, N. Engl. J. Med., 352, 1685-1695.

[13] van Eijk, M., van Roomen, C. P., Renkema, G. H., Bussink, A. P., Andrews, L., Blommaart, E. F., et al., (2005) Characterization of human phagocyte-derived chitotriosidase, a component of innate immunity, Int. Immunol., 17, 1505-12.

[14] Shaw, P. X., Hörkkö, S., Tsimikas, S., Chang, M. K., Palinski, W., Silverman, G. J., et al., (2001) Human-derived anti-oxidized LDL autoantibody blocks uptake of oxidized LDL by macrophages and localizes to atherosclerotic lesions in vivo, Arterioscler Thromb Vasc Biol, 21, 1333-9.

[15] Bláha, M., Cermanová, M., Bláha, V., Blazek, M., Malý, J., Siroký, O., et al., (2007) Safety and tolerability of long lasting LDL-apheresis in familial hyperlipoproteinemia. Ther Apher Dial, 11, 9-15.

[16] Hixson, J. E. and Vernier, D. T., (1990) Restriction isotyping of human apolipoprotein $\mathrm{E}$ by gene amplification and cleavage with HhaI, J. Lipid. Res., 31, 545-8.

[17] Tsukamoto, K., Watanabe, T., Matsushima, T., Kinoshita, M., Kato, H., Hashimoto, Y., Kurokawa, K., and
Teramoto, T., (1993) Determination by PCR-RFLP of apo E genotype in a Japanese population, J. Lab. Clin. Med., 121, 598-602.

[18] Hulthe, J., Wikstrand, J., Lidell, A., Wendelhag, I., Hansson, G. K., and Wiklund, O., (1998) Antibody titers against oxidized LDL are not elevated in patients with familial hypercholesterolemia, Arterioscler Thromb Vasc Biol, 18, 1203-1211.

[19] Tinahones, F. J., Gomez-Zumaquero, J. M., RojoMartinez, G., Cardona, F., Esteva de Antonio, I. E., Ruiz de Adana, M. S., et al., (2002) Increased levels of anti-oxidized low-density lipoprotein antibodies are associated with reduced levels of cholesterol in the general population, Metabolism, 51, 429-31.

[20] Tinahones, F. J., Gomez-Zumaquero, J. M., GarridoSanchez, L., Garcia-Fuentes, E., Rojo-Martinez, G., Esteva, I., et al., (2005) Influence of age and sex on levels of anti-oxidized LDL antibodies and anti-LDL immune complexes in the general population, J. Lipid. Res., 46, 452-7.

[21] Canudas, J., Cenarro, A., Civeira, F., García-Otín, A. L., Arístegui, R., Díaz, C., et al., (2001) Chitotriosidase genotype and serum activity in subjects with combined hyperlipidemia: Effect of the lipid-lowering agents, atorvastatin and bezafibrate, Metabolism, 50, 447-450.

[22] Brizzi, P., Tonolo, G., Bertrand, G., Carusillo, F., Severino, C., Maioli, M., et al., (2004) Autoantibodies against oxidized low-density lipoprotein (oxLDL) and LDL oxidation status, Clin. Chem. Lab. Med., 42, 164-70.

[23] Frostegård, J., Tao, W., Georgiades, A., Råstam, L., Lindblad, U., and Lindeberg, S., (2007) Atheroprotective natural anti-phosphorylcholine antibodies of $\operatorname{IgM}$ subclass are decreased in Swedish controls as compared to non-westernized individuals from New Guinea, Nutr Metab (Lond), 20, 7.

[24] Binder, C. J., Chang, M. K., Shaw, P. X., Miller, Y. I., Hartvigsen, K., Dewan, A., et al., (2002) Innate and acquired immunity in atherogenesis, Nat. Med., 8, 1218-26.

[25] Palinski, W., Miller, E., Witztum, J. L., (1995) Immunization of low density lipoprotein (LDL) receptor-deficient rabbits with homologous malondialdehyde-modified LDL reduces atherogenesis, Proc. Natl. Acad. Sci., USA, 92, 821-5.

[26] Binder, C. J., Hörkkö, S., Dewan, A., Chang, M. K., Kieu, E. P., Goodyear, C. S., et al., (2003) Pneumococcal vaccination decreases atherosclerotic lesion formation: molecular mimicry between Streptococcus pneumoniae and oxidized LDL, Nat. Med., 9, 736-43.

[27] Ameli, S., Hultgardh-Nilsson, A., Regnstrom, J., Calara, F., Yano, J., Cercek, B., et al., (1996) Effect of immunization with homologous LDL and oxidized LDL on early atherosclerosis in hypercholesterolemic rabbits, Arteri-oscler Thromb Vasc Biol, 16, 1074-9.

[28] Pappalardo, F., Musumeci, S., and Motta, S., (2008) Modeling immune system control of atherogenesis, Bioinformatics.

[29] Orem, C., Orem, A., Uydu, H. A., Celik, S., Erdol, C., and Kural, B. V., (2002) The effects of lipid-lowering therapy on low-density lipoprotein auto-antibodies: Relationship with low-density lipoprotein oxidation and plasma total antioxidant status, Coron Artery Dis, 13, 65-71.

[30] Brizzi, P., Isaja, T., D'Agata, A., Malaguarnera, L., Malaguarnera, M., and Musumeci, S., (2002) Oxidized LDL antibodies (OLAB) in patients with beta thalassemia major, J. Atheroscler Thromb, 9, 139-44. 